\title{
PENEGAKAN HUKUM TERHADAP TINDAK PIDANA PENIMBUNAN OBAT-OBATAN TERAPI COVID-19
}

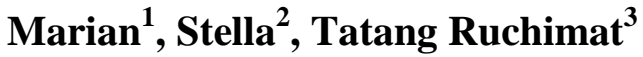 \\ ${ }^{1}$ Fakultas Hukum, Universitas Tarumanagara \\ Email: marian.205210051@stu.untar.ac.id \\ ${ }^{2}$ Fakultas Hukum, Universitas Tarumanagara \\ Email: stella.205210294@stu.untar.ac.id \\ ${ }^{3}$ Fakultas Hukum, Universitas Tarumanegara \\ Email: tatangruchimat1@gmail.com
}

\begin{abstract}
It has been almost two years since the COVID-19 pandemic devastated Indonesia. This, of course, forces the community and the government to face various problems and new polemics. However, the government did not just let go and always tried to overcome it so that the burden on the community during the Covid-19 pandemic could be lighter. This article was created to know the law enforcement carried out by the government by following applicable laws and regulations in overcoming the problem of hoarding Covid-19 therapeutic drugs and to examine the factors that influence the law enforcement process against the criminal act of hoarding Covid-19 therapeutic drugs. The research methodology used is normative legal research, centered on the use of library materials as a source of information. This research uses a qualitative approach by combining data and collective information from various sources which is then developed from a sociological point of view. The perpetrators of hoarding Covid-19 therapeutic drugs can be charged with several articles of criminal law as regulated in-laws and regulations, including Law No. 7 of 2014, Law No. 36 of 2009, and so on, with a maximum prison sentence of 10 years. However, in practice, the law enforcement process is very dependent on several factors, such as legislation, law enforcement officers, the availability of facilities and facilities, as well as the community. The Covid-19 pandemic has put people in a state of panic and the need for medicines has increased drastically, so efforts are urgently needed to deter hoarders and hope that similar incidents will not happen again. Law enforcers need to make legal breakthroughs in cracking down on drug hoarders, and also make other efforts such as revocation of permits, fines, and confiscation of stockpiled drugs to be subsequently given to people in need, also need to consider the characteristics of one case with another by following scale of stockpiling and types of drugs.
\end{abstract}

Keywords = law enforcement, hoarding, Covid-19 drugs

\begin{abstract}
ABSTRAK
Hampir dua tahun lamanya Pandemi Covid-19 telah memporakporandakan Indonesia. Hal itu tentu memaksa masyarakat dan juga pemerintah untuk menghadapi berbagai permasalahan hingga polemik baru. Namun pemerintah lantas tak lepas tangan begitu saja dan selalu berusaha untuk mengatasinya agar beban masyarakat di masa pandemi Covid-19 dapat lebih diringankan. Artikel ini dibuat dengan tujuan untuk mengetahui penegakan hukum yang dilakukan oleh pemerintah sesuai dengan peraturan perundang-undangan yang berlaku dalam mengatasi masalah penimbunan obat terapi Covid-19 serta menelaah faktor-faktor yang berpengaruh pada proses penegakan hukum terhadap tindak pidana penimbunan obat terapi Covid-19. Metodologi penelitian yang digunakan adalah penelitian hukum normatif, berpusat pada penggunaan bahan pustaka sebagai sumber informasi. Penelitian ini menggunakan pendekatan kualitatif dengan mengkombinasikan data dan informasi kolektif dari berbagai sumber yang kemudian dikembangkan dengan sudut pandang sosiologis. Pelaku penimbun obat terapi Covid-19 dapat dijerat dengan beberapa pasal hukum pidana sebagaimana diatur dalam peraturan perundang-undangan, antara lain UU No. 7 Tahun 2014, UU No.36 Tahun 2009,dan lain sebagainya, dengan ancaman hukuman penjara maksimal 10 tahun. Namun pada prakteknya proses penegakan hukum sangat bergantung pada beberapa faktor seperti peraturan perundang-undangan, aparat penegak hukum, ketersediaan sarana dan fasilitas serta masyarakat. Pandemi Covid-19 telah membuat masyarakat berada dalam kepanikan dan kebutuhan obat-obatan pun meningkat drastis, sehingga sangat diperlukan daya upaya agar para penimbun menjadi jera dan kejadian serupa diharapkan tidak terulang kembali. Penegak hukum perlu melakukan terobosan hukum dalam menindak tegas penimbun obat, dan juga melakukan upaya lain seperti pencabutan izin, sanksi denda, dan penyitaan obat-obatan yang ditimbun untuk selanjutnya diberikan kepada masyarakat yang membutuhkan, juga perlu mempertimbangkan karakteristik kasus satu dengan yang lain sesuai dengan skala penimbunan dan jenis obat-obatannya.
\end{abstract}

Kata kunci $=$ penegakan hukum, penimbunan, obat Covid-19 


\section{PENDAHULUAN}

Pandemi Covid-19 telah mencetak sejarah sebagai pandemi terparah di abad modern. Krisis yang bermula dari masalah kesehatan lalu memporak-porandakan berbagai aspek kehidupan lainnya. Melonjaknya kasus positif pasien Covid-19 setiap harinya lantas membuat pemerintah dan tenaga kesehatan semakin kewalahan. Seiring dengan merebaknya berbagai macam varian virus jenis baru, angka kasus pun semakin tak terkendali. Fasilitas kesehatan seperti rumah sakit dan puskesmas tidak mampu untuk menampung semua pasien Covid-19 sehingga beberapa pasien terpaksa untuk melakukan isolasi mandiri. Gejala yang diderita oleh pasien Covid-19 bisa berbeda-beda tergantung dari jenis varian virus yang menginfeksi dan kondisi tubuh masingmasing orang. Masyarakat pun berusaha untuk membekali dirinya dengan obat terapi Covid-19 walau belum terinfeksi. Hal ini berimbas pada tingginya permintaan akan obat terapi Covid-19 sehingga menambah potensi kelangkaan.

Sedari dulu praktek 'aji mumpung' kerap kali terjadi di masyarakat. Terlebih dalam situasi yang genting seperti saat pandemi ini, masih saja ada oknum pelaku pasar yang mengambil 'kesempatan di dalam kesempitan', yaitu dengan cara menimbun stok obat-obatan terapi Covid19. Nantinya barang-barang yang ditimbun akan dijual dengan harga yang tinggi untuk meraup keuntungan yang besar. Padahal perbuatan tersebut jelas-jelas bisa mencelakakan orang lain. Pasien positif Covid-19 terutama yang tidak mendapatkan ruang di rumah sakit dan melakukan isolasi mandiri terpaksa harus mencari pasokan obat-obatan mereka sendiri. Banyak rakyat menderita dan tak sedikit pula yang kehilangan nyawa karena ketidakmampuan untuk memperoleh obat terapi Covid-19. Oknumnya bukan hanya dari kalangan pedagang atau pengusaha, bahkan tenaga kesehatan pun terlibat dalam kasus penimbunan obat terapi Covid-19. Para pelaku yang diamankan polisi dijerat dengan pasal yang berbeda-beda disesuaikan dengan jenis pelanggarannya.

Dalam upaya untuk menanggulangi masalah terkait Covid-19, Kapolri pun meminta para Kapolda di seluruh Indonesia untuk menguasai penerapan pasal dan melakukan koordinasi dengan pihak kejaksaan terkait beberapa pasal yang dapat disangkakan kepada para pelaku penimbunan obat terapi Covid-19.(Nur Habibie,2021)

Tingkat permintaan obat terkait Covid-19 yang sangat tinggi membuat segelintir orang tergiur untuk mengeruk keuntungan sebanyak-banyaknya dengan menghalalkan segala cara. Ada beberapa kasus yang belakangan ini cukup menarik perhatian publik, contohnya kasus penimbunan obat Covid-19 yang menjerat PT ASA.Polisi berhasil menemukan sejumlah jenis obat terkait penanganan Covid-19, antara lain jenis obat Azithromycin, Dexamethasone, dan lain sebagainya di dalam gudang milik PT ASA. Kejadian tersebut bermula dari adanya laporan warga tentang dugaan penimbunan obat di gudang milik PT ASA di Kalideres, Jakarta Barat, lalu berbuntut ditetapkannya Direktur Utama dan Komisaris Utama PT ASA sebagai tersangka kemudian disangkakan dengan pasal terberatnya, yakni Pasal 107 jo Pasal 29 Ayat (1) UU No. 7 Tahun 2014 tentang Perdagangan, dengan ancaman hukuman penjara paling lama 5 tahun. Pemeriksaan terhadap Dirut dan Komut PT ASA pun dilakukan 3-4 Agustus 2021. Usai diperiksa pada tanggal 3 Agustus 2021, Dirut PT ASA tidak langsung ditahan oleh kepolisian dan diharuskan wajib lapor dengan alasan kesehatan. Keesokannya, giliran Komisaris Utama PT ASA untuk diperiksa dan ia ditahan satu hari setelahnya, yakni pada tanggal 5 Agustus 2021. Kemudian pada tanggal 6 Agustus 2021, Dirut PT ASA langsung ditahan polisi setelah dinyatakan layak oleh unit kedokteran dan kesehatan Polres Jakarta Barat.(Sonya Teresa Debora,2021)

Kasus lainnya ialah kasus yang melibatkan oknum tenaga kesehatan (perawat) dan apoteker. Setiap profesi terutama perawat dan apoteker tentunya memiliki kode etik yang menjadi landasan dalam melakukan pekerjaannya, di mana kode etik itu sendiri bertujuan untuk melayani masyarakat secara khusus dan sepenuh hati dengan mengesampingkan kepentingan pribadi atau 
kelompok. Tim Ditresnarkoba Polda Metro Jaya berhasil mengungkap kejahatan yang dilakukan oleh sindikat penimbunan obat terapi Covid-19. Sindikat itu beranggotakan 24 orang, di antaranya ada yang berprofesi sebagai perawat serta ada pula yang bekerja sebagai apoteker. Pihak kepolisian menyita ribuan butir dan puluhan vial obat terapi Covid-19 berbagai merek, terutama jenis obat antivirus yang biasa diresepkan untuk pasien-pasien Covid-19. Obat-obat tersebut diperoleh dengan berbagai modus, mulai dari oknum perawat yang berperan untuk mencuri sisa obat-obatan pasien Covid-19 yang tak bisa diselamatkan, hingga memalsukan resep dan bekerja sama dengan oknum apoteker.

Obat-obatan yang terkumpul kemudian ditimbun dan dijual kembali melalui market place atau media sosial dengan harga berpuluh kali lipat dibanding harga eceran tertinggi (HET) yang telah ditetapkan pemerintah. Salah satu contohnya ialah obat jenis Actemra yang dijual dengan harga 40 juta rupiah di mana HETnya sebesar Rp1.162.200 (hampir 40 kali lipat) dan tentu saja menyalahi Kepmenkes No. HK.01.07/MENKES/4826/2021 tentang Harga Eceran Tertinggi Obat Dalam Masa Pandemi Covid-19. Para pelaku dijerat Pasal 196 dan atau Pasal 198 UU No. 36 Tahun 2009 tentang Kesehatan dan atau Pasal 62 jo Pasal 10 UU No. 8 Tahun 1999 tentang Perlindungan Konsumen, karenanya mereka terancam hukuman pidana maksimal 10 tahun penjara. Barang bukti yang telah disita rencananya akan dipergunakan untuk kepentingan masyarakat dengan cara dilelang, kemudian uang hasil lelang yang akan dijadikan barang bukti ke pengadilan. Namun untuk merealisasikannya pihak polisi perlu berkoordinasi terlebih dahulu dengan Kejaksaan Tinggi DKI Jakarta.(Anonym,2021)

Setali tiga uang dengan apa yang tertuang dalam Hukum Islam yang menyatakan bahwa penimbunan haram hukumnya, MUI dan pemerintah Indonesia pun melarang tindakan penimbunan yang dapat menimbulkan kepanikan maupun kerugian pada masyarakat. Sudah sewajarnya sebagai masyarakat yang menjujung tinggi kemanusiaan, seseorang dapat memahami dan turut membantu satu sama lain, tak terkecuali dalam kondisi yang memperihatinkan seperti saat pandemi Covid-19 ini. Dengan meringankan penderitaan sesama, maka otomatis sebagai makhluk sosial, perbuatan tersebut akan memberikan makna tersendiri, dan pasti akan ada karma baik yang dapat dituai.

\section{Rumusan Masalah}

Berdasarkan uraian di atas, dapat diidentifikasikan masalah sebagai berikut:

1. Bagaimanakah pelaksanaan penegakan hukum terhadap pelaku tindak pidana penimbunan obat terapi Covid-19?

2. Faktor-faktor apakah yang mempengaruhi penegakan hukum terhadap pelaku tindak pidana penimbunan obat terapi Covid-19?

\section{Tujuan Penelitian}

Adapun penelitian ini dilakukan dengan tujuan untuk mengetahui pelaksanaan penegakan hukum yang telah dilakukan terhadap pelaku tindak pidana penimbunan obat terapi Covid-19 dan juga mengetahui faktor-faktor yang mempengaruhi proses penengakan hukum terhadap pelaku tindak pidana penimbunan obat terapi Covid-19, serta dengan harapan dapat menjadi bahan pertimbangan bagi aparatur negara dalam menentukan sanksi yang akan dijatuhkan kepada para pelaku tindak pidana penimbunan obat terapi Covid-19.

\section{METODE PENELITIAN}

Metodologi yang digunakan penelitian ini adalah penelitian hukum normatif, yakni jenis penelitian yang dipahami sebagai penelitian untuk menguji suatu norma atau ketentuan yang berlaku.(Irwansyah, 2020 :42) Penelitian ini menggunakan data sekunder sebagai fokus kajiannya, yakni bahan pustaka yang terdiri dari bahan hukum primer (perundang-undangan) dan 
bahan hukum sekunder (buku, artikel, makalah).(Soerjono Soekanto \& Sri Mamudji, 2019: 1213) Lalu dihubungkan dengan objek dan nilai yang dikembangkan berdasarkan sudut pandang sosiologis yang mana memandang hukum sebagai fenomena atau realitas di antara hubungan masyarakat dan pengaruhnya secara timbal balik dengan sistem lain di luar hukum.(Irwansyah, 2020: 21) Dalam hal ini berupa perilaku masyarakat Indonesia di tengah kelangkaan obat terapi Covid-19, serta bagaimana pihak berwajib melakukan penegakan hukum dengan contoh kasus yang telah terjadi.

Penelitian ini bersifat deskriptif, yaitu dengan memberikan penggambaran peristiwa dengan menggunakan data yang telah dikumpulkan sebelumnya lalu ditelaah secara kualitatif dihubungkan dengan norma yang berlaku.

\section{HASIL DAN PEMBAHASAN}

\section{Penegakan Hukum Tindak Pidana Penimbunan Obat Terapi Covid-19}

Dalam pelaksanaan hukum di dalam masyarakat, selain kesadaran hukum masyarakat, juga ditentukan oleh pribadi dari aparat penegak hukum yang terlibat (Sanyoto,2008). Di dalam beberapa kasus yang terjadi ada oknum aparat yang tidak melaksanakan tugas sebagaimana mestinya. Penegakan hukum pidana sendiri meliputi dua hal, yakni penegakan hukum pidana in abstracto dan penegakan hukum pidana in concreto. Menurut Aji Lukman Ibrahim \& Rianda Dirkareshza pada artikel berjudul Penimbunan Masker dan Hand Sanitizer di Masa Pandemi Covid-19, dalam Abdul Halim, et.all, (202:443), penegakan hukum pidana in abstracto masih bersifat abstrak, di mana hukum dalam bentuk yang tersirat dan bersifat mencegah terjadinya tindak pidana. Sedangkan penegakan hukum pidana in concreto adalah suatu tindakan konkret dari aparat penegak hukum dalam menegakkan aturan hukum pidana. Tindakan inilah yang sesungguhnya menjadi urgensi dalam merealisasikan tujuan keberadaan hukum.

Kasus yang menjerat PT ASA serta sindikat yang melibatkan oknum perawat dan apoteker, menjadi bukti bahwa keserakahan tidak dapat dinilai berdasarkan apa profesinya. Bayangkan ada berapa banyak orang positif Covid-19 yang seharusnya dapat menjangkau obat-obatan terapi itu, dan berapa banyak pula yang pada akhirnya harus meninggal karena tidak mampu untuk membeli obat terapi Covid-19, entah karena kelangkaan barang atau karena tidak mampu untuk membayar harga yang mahal. Bukan hanya dapat mencelakakan nyawa seseorang, penimbunan obat Covid-19 juga bisa menjadi penyebab gejolaknya perekonomian negara.

Nabi SAW, bersabda 'Barangsiapa melakukan penimbunan, maka ia dianggap bersalah' dalam Hadis yang diriwayatkan oleh Abu Daud, At-Tirmidzi dan Muslim dari Mu'ammar.(Sudirman, 1995: 131) Jelas diisyaratkan bahwa penimbunan barang dagangan, tak terkecuali obat terapi Covid-19, adalah perbuatan yang salah dan menyimpang dari Hukum Islam. Apalagi perbuatan tersebut jelas-jelas menjurus pada ketamakan dan keburukan moral yang menyengsarakan sesama umat manusia.

Sejalan dengan Hukum Islam, pemerintah Indonesia pun menentang penimbunan barang yang dapat menimbulkan penderitaan rakyat. Hal tersebut terbukti telah diatur dalam beberapa peraturan perundang-undangan. Dalam kasus PT ASA, Direktur Utama dan Komisaris Utama dijerat Pasal 107 jo Pasal 29 Ayat (1) UU No. 7 Tahun 2014, Pasal 62 Ayat (1) jo Pasal UU No. 8 Tahun 1999, Pasal 5 Ayat (1) UU No. 4 Tahun 1984, di mana ancaman maksimalnya adalah kurungan selama lima tahun penjara dan atau denda lima puluh milyar rupiah. Pasal dan ancaman hukuman yang menjerat pemimpin PT ASA serupa dengan yang menjerat pelaku penimbun masker pada tahun 2020 silam, yakni Pasal 107 Undang-Undang Nomor 7 Tahun 2014 tentang Perdagangan.(Yuliawati, 2020) Padahal, penimbunan obat terapi Covid-19 lebih krusial dan membahayakan rakyat karena mempertaruhkan seseorang secara langsung sehingga pelakunya perlu dijerat hukuman yang lebih berat ketimbang pelaku yang menimbun masker. 
Proses penahanan Dirut dan Komut PT ASA dilaksanakan sebagaimana telah diatur dalam:

1) Pasal 21 ayat (1) KUHAP menyatakan bahwa perintah penahanan tersangka tindak pidana dilakukan sebagai langkah preventif kemungkinan hal-hal negatif yang dapat dilakukan oleh tersangka dan jelas ditentang oleh undang-undang, yang mana berlaku pada tersangka dengan ancaman kurungan minimal 5 tahun.

2) Pasal 7 ayat (1) huruf b) dan j) KUHAP tertuang tentang kewenangan penyidik untuk melakukan tindakan awal di tempat pertama, serta bertanggung jawab mengadakan tindakan lain yang baik menurut hukum.

3) UU No. 2 Pasal 18 Tahun 2002 tentang Kepolisian Negara Republik Indonesia, dinyatakan bahwa pejabat kepolisian RI memiliki kewenangan dalam bertugas dan bertindak berdasarkan perspektifnya sendiri apabila diperlukan tanpa mengabaikan etika profesi serta ketentuan yang berlaku.

Berdasarkan ketentuan undang-undang yang diuraikan di atas dapat terlihat bahwa penundaan penahaan yang dilakukan adalah sah. Namun, ada poin-poin pada Pasal 7 Ayat (1) KUHAP yang menyiratkan salah satu unsur dalam penahanan adalah unsur subjektif di mana unsur ini bersumber pada penilaian oleh penyidik tentang suatu keadaan tersangka atau terdakwa. Hal inilah yang dalam praktiknya menjadikan penegak hukum terlalu memiliki kuasa untuk menentukan seorang tersangka ditahan atau malah sebaliknya.(Shafira Candra Dewi, 2021)

Kasus penimbunan obat terapi Covid-19 yang berikutnya adalah kasus yang melibatkan seorang oknum perawat dan apoteker. Sebelum melaksanakan pekerjaannya, seorang perawat terlebih dahulu diambil sumpahnya. Sumpah dilontarkan merupakan janji perawat tersebut kepada Tuhan, bangsa, dan negara. Selain sumpah, ada juga pernyataan untuk menaati kode etik. Begitu pula dengan seorang apoteker. Namun dalam kasus ini, oknum perawat dan apoteker sama sekali melupakan sumpah dan kode etik yang mereka nyatakan sebelum menjalankan profesi. Mereka bekerja sama dengan 22 orang lainnya membentuk suatu sindikat penimbun obat terapi Covid19. Sindikat itu disangkakan Pasal 196 dan/atau Pasal 198 UU Nomor 36 Tahun 2009 tentang Kesehatan dan/atau Pasal 62 jo Pasal 10 UU Nomor 8 Tahun 1999 tentang Perlindungan Konsumen, di mana ancaman maksimalnya adalah sepuluh tahun penjara dan atau denda maksimal satu miliar rupiah.

Menimbang dari profesi yang dijalani pelaku, di mana profesi tersebut seharusnya memberikan pelayanan kepada masyarakat serta menjauhkan diri dari usaha mencari keuntungan diri sendiri, maka aparat penegak hukum harus memberikan putusan hukum seberat-beratnya selain sanksi administratif berupa pencabutan ijin. Sejatinya hukum dibuat sebagai alat untuk mencapai suatu kondisi yang ideal serta mengutamakan kepentingan umum. Keberadaan hukum tak seharusnya diabaikan begitu saja, seperti apa yang telah dilakukan oleh para oknum nakal yang melakukan penimbunan obat terapi Covid-19 di tengah kondisi bangsa yang sedang sekarat, di mana banyak korban telah berjatuhan.

Bukan hanya itu, proses penegakan hukum terhadap oknum-oknum penimbunan obat pada kasus yang telah disebutkan sebelumnya, hingga kini belum mengalami kemajuan sehingga menimbulkan kesan jalan di tempat. Hal-hal seperti ini yang pada akhirnya memberikan efek domino pada meningkatnya kasus-kasus serupa. Lambat laun hukum mengalami kemunduran pada fungsinya dalam mengatur masyarakat, karena sikap pemerintah dan aparat yang kurang tegas dalam menegakan hukum, sehingga mengakibatkan tujuan hukum gagal untuk dicapai.

\section{Faktor-Faktor yang Mempengaruhi Penegakan Hukum Tindak Pidana Penimbunan Obat Terapi Covid-19}

Kasus penimbunan obat terapi Covid-19 yang menjerat PT ASA dan Sindikat yang melibatkan tenaga kesehatan merupakan kasus yang berhasil diungkap oleh kepolisian, yang mana kasuskasus tersebut tidak seberapa dari banyaknya tindak pidana penimbunan obat terapi Covid-19 
yang sesungguhnya telah terjadi. Ada beberapa hal yang tentunya menjadi kendala dalam proses penegakan hukum, dan kendala tersebut dipengaruhi oleh beberapa faktor :

1) Peraturan perundang-undangan yang berlaku.

2) Aparat penegak hukum.

3) Ketersediaan sarana atau fasilitas.

4) Bagaimana masyarakat menerapkan suatu hukum yang berlaku.

5) Kebudayaan.(Soerjono Soekanto, 1983: 8)

Faktor yang pertama adalah faktor perundang-undangan. Undang-undang dibuat dengan tujuan untuk memberikan dampak positif terhadap kehidupan masyarakat, salah satu asas yang berpengaruh adalah undang-undang tidak berlaku surut yang artinya undang-undang hanya bisa diterapkan pada peristiwa yang disebut pada undang-undang itu dan peristiwa yang dipermasalahkan harus terjadi setelah undang-undang tersebut dibuat dan diberlakukan.(Irwansyah, 2020: 89) Pada permasalahan penimbunan obat-obatan Covid-19 ini ada undang-undang, seperti Pasal 14 UU No 4 Tahun 1984 tentang Wabah Penyakit Menular, yang sifatnya masih terlalu luas dan cair sehingga penegak hukum menemui kesulitan dalam menentukan jenis tindakan pelanggaran karena kasus penimbunan obat-obatan ini dapat dikategorikan sebagai suatu pelanggaran yang dikarenakan kelalaian atau bisa juga sebagai suatu tindak kejahatan yang disengaja jadi terkadang ada ketimpangan dalam menindak satu kasus dengan kasus lainnya. (Rizky Syahputra, 2021)

Faktor yang kedua adalah aparat penegak hukum. Di dalam tulisan ini yang dimaksud dengan penegak hukum akan dibatasi pada kalangan yang secara langsung berkecimpung dalam bidang penegakan hukum seperti hakim, jaksa,dan polisi. Seorang penegak hukum dalam menjalankan tugasnya mempunyai kedudukan dan peranan sekaligus. Terkadang timbul berbagai konflik atas kedudukan dan peranan tersebut, di dalam kenyataannya seringkali ada kesenjangan antara peranan yang seharusnya dan peranan aktual atau yang sebenarnya dilakukan. Masalah peranan ini akan berdampak pada munculnya diskresi. Diskresi menyangkut pengambilan keputusan yang tidak sangat terikat oleh hukum, dimana pada saat pengambilan keputusan penilaian pribadi ikut memegang peranan. Dalam kasus penegakan hukum terhadap petinggi PT ASA muncul diskresi dalam bentuk penyelewengan wewenang. Faktor penegak hukum, dalam hal ini adalah aparat penegak hukum yang menentukan pasal-pasal yang disangkakan dan dalam proses penahanan petinggi PT ASA, penyidik yang mana memiliki wewenang, secara subjektif menentukan untuk melakukan penangguhan penahanan.

Faktor ketiga adalah faktor sarana dan fasilitas . Kelancaran penegakan hukum ikut didukung oleh adanya sarana dan fasilitas, contohnya tenaga manusia yang berpendidikan dan terampil, jumlah tenaga yang memadai, peralatan yang mendukung. Tanpa hal-hal tersebut mustahil penegakan hukum akan mencapai tujuannya. Kasus PT ASA dan sindikat yang melibatkan tenaga kesehatan dan apoteker hanya merupakan segelintir dari kasus-kasus yang sesungguhnya terjadi di tengah masyarakat. Dengan keterbatasan fasilitas, penegak hukum kesulitan membongkar semua kasus yang ada, terutama kasus yang memanfaatkan media sosial sebagai media pemasarannya sehingga pihak berwajib sulit untuk menindak pelaku.

Dalam menegakan hukum pun prosesnya terkesan lambat, faktor ketersediaan penegak hukum seperti hakim, jaksa, dll yang masih kurang mumpuni ikut memberi pengaruh, terlebih lagi kita sedang berada dalam situasi pandemi dimana proses pengadilan harus dilakukan secara daring dan belum ada regulasi yang mengaturnya, sedangkan proses pengadilan harus berjalan terus terutama pada masa pandemi ini dimana masyarakat berada dalam kepanikan akan terpenuhinya kebutuhan obat-obatan (Aji Lukman Ibrahim dan Rianda Dirkareshza, 2021: 443-463). Penegakan hukum perlu dilaksanakan sehingga ada efek jera terhadap pelaku dan kejadian serupa tidak terulang kembali. 
Faktor ke empat adalah faktor masyarakat. Penegakan hukum terjadi akibat adanya permasalahan di masyarakat dan tujuan dari penegakan hukum ini adalah terciptanya kedamaian di masyarakat. Oleh sebab itu masyarakat ikut berpengaruh dalam penegakan hukum, hal ini juga masih ada kaitannya dengan faktor-faktor sebelumnya, yaitu undang-undang, penegak hukum, dan sarana atau fasilitas.

Dalam kasus penimbunan obat-obatan Covid-19 ini pelaku tindak pidana memanfaatkan moment kelangkaan obat-obatan Covid-19 demi meraup keuntungan besar. Manusia modern cenderung mengedepankan rasionalitas dan logika dan mulai mengesampingkan kebijaksanaan (Fahruddin Faiz, 2021).Terlebih lagi kasus penimbunan obat-obatan Covid-19 ini melibatkan profesi tenaga kesehatan dan apoteker dimana mereka mempunyai kode etik yang harus dijunjung tinggi serta mengemban kepercayaan yang sudah diberikan kepada masyarakat (Ikatan Apoteker Indonesia, 2014). Terlepas dari oknum penimbun obat-obatan Covid-19 yang berasal dari masyarakat, ada pula masyarakat yang ikut membantu dalam proses penegakan hukum yaitu warga yang melaporkan kecurigaan adanya praktek penimbunan di gudang milik PT ASA.

Pengusaha alkes dan obat-obat seyogyanya tidak hanya berpikir untuk mendapatkan keuntungan, tatkala tingkat permitaan tinggi. Dalam situasi pandemi, perlu dibangun sikap mental yang mengedepankan empati dan tanggung jawab sosial sebagai bagian dari masyarakat itu sendiri sehingga kalau pun ingin mengambil keuntungan, tentunya tetap harus mempertimbangkan hati nurani, kesusilaan, kepatutan, norma-norma agama, dan sebagainya. Seperti diketahui bersama bahwa dalam situasi pandemi membawa akibat lanjutan berupa resesi ekonomi akibat banyak perusahaan yang tidak mampu menjaga cost structure yang menjadi timpang sehingga perusahaan mengalami permasalahan terhadap cash flow. Situasi ini juga berimbas pada pengurangan pegawai (pegawai dirumahkan), sampai pada penutupan kegiatan usaha. Bagi perusahaan-perusahaan yang kebetulan fokus bisnisnya di bidang alat kesehatan dan obat-obatan tidaklah elok dan patut jika kemudian berpikir aji mumpung dengan memanfaatkan sutuasi yang ada dengan berdasarkan pinsip kelangkaan.

Bagaimana pun juga seorang pengusaha di negara kesatuan republik indonesia yang ber'Pancasila mengemban mission sacre sebagai perpanjang tangan Tuhan dan mitra pemerintah dalam melaksanakan pembangunan atau mengatasi suatu permasalahan yang terjadi pada kurun waktu tertentu. Berkenaan dengan itu, pemerintah perlu memberikan toleransi bagi kenaikkan harga obat-obatan sepanjang hal tersebut tidak memberatkan masyarakat, sehingga fungsi-fungsi negara dapat diperasionalkan dan diwujudkan secara utuh dalam sutuasi pandemi Covid-19. Seperti halnya ketika hari raya, pengusaha transportasi diperbolehkan untuk menaikkan harga tarif transpotasi mudik untuk waktu tertentu. Hal tersebut bisa ditetapkan dalam aturan yang dijadikan sebagai rujukan pelaksanaan penanganan Covid-19, contohnya seperti Perpres, PP, Perda, dan lain lain.(hasil wawancara dengan Yuwono Prianto)

\section{KESIMPULAN DAN SARAN}

Penegakan hukum di Indonesia terhadap pelaku tindak pidana penimbunan obat terapi Covid-19 yang dilakukan oleh PT ASA dan oknum nakes dapat dikatakan cenderung bersifat represif, dengan menahan para pelaku dan menjeratnya dengan peraturan perundang-undangan yang berlaku, yakni berupa ancaman hukuman penjara dan atau pun sanksi denda, walaupun sesungguhnya telah dilakukan terlebih dahulu upaya-upaya persuasif sebelumnya dengan maksud memberikan kesadaran supaya tindak pidana penimbunan obat terapi Covid-19 dapat dicegah. Meskipun demikian, upaya pemerintah dalam menegakan hukum dinilai belum optimal dan tidak membuat para pelaku menjadi jera. Masih banyak oknum-oknum lain yang bebas dari jeratan hukum dan tetap melakukan praktek penimbunan yang menyulitkan banyak orang. Padahal sepatutnya tindakan penegakan hukum itu menjadi instrumen utama dalam mengeksekusi hukum itu sendiri. 
Pada prakteknya, proses penegakan hukum juga tak bisa lepas dan masih terbelenggu oleh beberapa aspek, seperti faktor perundang-undangan, aparat penegak hukum, fasilitas dan sarana, serta faktor masyarakat. Dalam mengimplementasikan suatu perundang-undangan masih terdapat kendala dimana isi dari undang-undang itu sendiri bersifat terlalu luas atau rancu dalam penulisannya sehingga sulit untuk menentukan jenis tindakan pelanggaran. Ada pula unsur subjektif dari aparat penegak hukum yang jelas berpengaruh besar pada tingkat efektivitas hukum yang berlaku sehingga sering terkesan 'pilih kasih' dalam realisasinya. Selain itu, ada keterbatasan dalam pelaksanaan proses pengadilan dikarenakan fasilitas dan sarana yang kurang memadai serta perilaku masyarakat yang mulai menyimpang dengan mengesampingkan hati nurani serta kebijaksanaan dan hanya mengutamakan keuntungan diri sendiri.

Penegak hukum diharapkan lebih bijaksana dalam memperlakukan kasus satu dengan yang lain dengan mempertimbangkan hukuman yang diberikan kepada penimbun obat-obatan dengan skala kecil dan besar serta jenis obat-obatannya. Sanksi di tempat seperti pencabutan izin, penetapan denda dan penyitaan barang bukti bisa diberlakukan untuk oknum penimbun berskala kecil. Media dan masyarakat diharapkan berperan aktif untuk menyoroti kasus penimbunan ini terutama mengenai putusan pidana terhadap oknum penimbun. Masyarakat aktif melapor kepada pihak berwajib jika ada indikasi penimbunan barang di gudang serta penyimpangan harga obatobatan Covid-19.Mitra kelembagaan diharapkan ikut berperan dalam melindungi konsumen, misalnya asosiasi, lembaga, aliansi dan yayasan.

\section{Ucapan Terima Kasih (Acknowledgement)}

Puji syukur penulis panjatkan kepada Tuhan Yang Maha Esa atas terselesaikannya jurnal ini. Jurnal ini merupakan tugas untuk memenuhi mata kuliah PLKH-1 Metode Penelitian Hukum. Terwujudnya jurnal ini adalah berkat bimbingan dari dosen kami, oleh karena itu kami ingin menyampaikan terima kasih sedalam-dalamnya atas waktu dan bimbingan yang sudah diberikan oleh Bapak Yuwono Prianto, S.H., M.Hum. Tidak lupa juga kami haturkan rasa terima kasih kepada segenap keluarga yang sudah ikut memberi dukungan, doa, nasehat, dan motivasi hingga jurnal ini bisa terselesaikan. Semoga jurnal ini dapat memberi manfaat bagi semua pihak yang membutuhkan.

\section{REFERENSI}

Ady Anugrahadi. (2021). "Nakes Terlibat Kasus Penimbunan Obat Terapi Covid-19, Jual Actemra hingga Rp40 Juta". https://www.merdeka.com/peristiwa/nakes-terlibat-kasuspenimbunan-obat-terapi-covid-19-jual-actemra-hingga-rp40-juta.html, diakses pada tanggal 24 Agustus 2021 pukul 10.00 .

Aida Mardatillah. (2020).’Dilema Sidang Pidana Secara Online Selama Pandemi”. https://www.hukumonline.com/berita/baca/lt5ecd0b3940972/dilema-sidang-pidana-secaranline-saat-pandemi, diakses pada tanggal 26 Agustus 2021 pukul 14.00.

Aji Lukman Ibrahim dan Rianda Dirkareshza. 2021. Penimbunan Masker dan Hand Sanitizer di Masa Pandemi Covid-19, dalam Abdul Halim, et. all. (ed), Penegakan Hukum di Masa Pandemi Covid-19, 443-463. Kencana, Jakarta.

Fahruddin Faiz. (2021). "Penyakit Orang Modern Hari Ini-Ngaji Filsafat Dr. Fahruddin Faiz". https://www.youtube.com/watch?v=T_CHnIw_ChM\&feature=youtu.be, diakses pada tgl 27 Agustus 2021 pukul 15.00.

Ikatan Apoteker Indonesia. (2014) "Kongres Nasional XIX \& Kongres Ilmiah XX 2014. Kode Etik Apoteker Indonesia." https://repository.iaibanyumas.org/Kode-Etik-ApotekerIndonesia.pdf, diakses pada 29 Agustus 2021 pukul 15.00.

Irwansyah. (2020). Penelitian Hukum : Pilihan Metode \& Praktik Penulisan Artikel. Mirra Buana Media, Yogyakarta. 


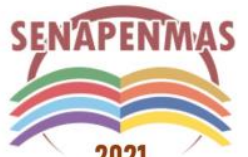

2021
Seminar Nasional Hasil Penelitian dan Pengabdian Kepada Masyarakat 2021 Pengembangan Ekonomi Bangsa Melalui Inovasi Digital Hasil Penelitian dan Pengabdian Kepada Masyarakat Jakarta, 21 Oktober 2021

Keputusan Menteri Kesehatan nomor HK.01.07/MENKES/4826/2021 tentang Harga Eceran Tertinggi Obat Dalam Masa Pandemi Covid-19.

Nur Habibie .(2021). "Kapolri Instruksikan Kapolda Tindak Tegas Penimbun Alkes dan Jual Obat di Atas HET". https://www.merdeka.com/peristiwa/kapolri-instruksikan-kapolda-tindaktegas-penimbun-alkes-dan-jual-obat-diatas-het.html, diakses pada tgl 27 Agustus 2021 pukul 11.00 .

Republik Indonesia. Undang-Undang Republik Indonesia Nomor 36 Tahun 2009 tentang Kesehatan. Lembaran Negara Republik Indonesia Tahun 2009 Nomor 5063.

Republik Indonesia. Undang-Undang Republik Indonesia no. 4 tahun 1984 tentang Penanggulangan Wabah Penyakit Menular. Lembaran Negara Republik Indonesia Tahun 1984 Nomor 20.

Republik Indonesia. Kitab Undang-Undang Hukum Acara Pidana (KUHAP). Lembaran Negara Nomor 76 Tahun 1981.

Rizky Syahputra. (2021). "Konsekuensi Hukum Bagi Penimbun Oksigen di Masa Pandemi”. https://www.ui.ac.id/konsekuensi-hukum-bagi-penimbun-oksigen-di-masa-pandemi/, diakses pada tanggal 26 Agustus 2021 pukul 13.00.

Sanyoto. (2008). "Penegakan Hukum di Indonesia". Jurnal Dinamika Hukum, vol. 8 (no.3), 2.

Shafira Candra Dewi. (2021). "Penahanan Menurut Undang-Undang Republik Indonesia Nomor 8 Tahun 1981 tentang Hukum Acara Pidana. Jurnal Studi Hukum Pidana Vol. 1 (no.1), 8.

Soerjono Soekanto \& Sri Mamudji. (2019). Penelitian Hukum Normatif: Suatu Tinjauan Singkat. Rajagrafindo Persada. Depok.

Soerjono Soekanto, (1983). Faktor-faktor yang Mempengaruhi Penegakan Hukum. PT RajaGrafindo Persada, Depok.

Sonya Teresa Debora. (2021)."Perjalanan Kasus PT ASA Diduga Timbun Obat Covid-19: Gudang Ditutup hingga Dirut Ditahan",

https://megapolitan.kompas.com/read/2021/08/07/06482691/perjalanan-kasus-pt-asa-didugatimbun-obat-covid-19-gudang-ditutup-hingga?page=all, diakses pada tanggal 25 Agustus 2021 pukul 13.00.

Sudirman. (1995). Penimbunan Barang Dalam Aktivitas Ekonomi Menurut Pandangan Hukum Islam, dalam Chuzaimah T. Yanggo (ed), Problematika Hukum Islam Kontemporer. Pustaka Firdaus, Jakarta.

Undang-Undang nomor 2 Tahun 2002 tentang Kepolisian Negara Republik Indonesia. Lembaran Negara Republik Indonesia Tahun 2002 Nomor 2.

Yuliawati. (2020). "Polisi Jerat Penimbun Masker dengan UU Perdagangan, Dendanya Rp 50 M".https://katadata.co.id/yuliawati/berita/5e9a470d2c892/polisi-jerat-penimbun-maskerdengan-uu-perdagangan-dendanya-rp-50-m, diakses pada tanggal 22 Agustus 2021 pukul 10.00 . 
Seminar Nasional Hasil Penelitian dan Pengabdian Kepada Masyarakat 2021

Pengembangan Ekonomi Bangsa Melalui Inovasi Digital Hasil Penelitian dan

Pengabdian Kepada Masyarakat

Jakarta, 21 Oktober 2021

(halaman kosong) 